\title{
Toxic effects of four kinds of dental restorative materials on fibroblast HGF-1 and impacts on expression of Bcl-2 and Bax genes
}

\author{
YUANYUAN WEI ${ }^{1}$, JIAN SUN $^{2}$, QINGLIN MEN ${ }^{1}$ and XIAOBEI TIAN ${ }^{2,3}$ \\ Departments of ${ }^{1}$ Prosthodontics and ${ }^{2}$ Endodontics, Xuzhou Stomatology Hospital; ${ }^{3}$ Teaching and \\ Research Office of Stomatology, Xuzhou Medical University, Xuzhou, Jiangsu 221003, P.R. China
}

Received October 16, 2017; Accepted August 23, 2018

DOI: $10.3892 /$ etm.2018.6705

\begin{abstract}
The aim of this study was to investigate and discuss the toxic effect of four kinds of dental restorative materials on fibroblast HGF-1 and their impacts on the expression of B-cell lymphoma-2 (Bcl-2) and Bcl-2-associated X protein (Bax) genes. One hundred and ninety-two patients (240 diseased teeth), who received dental restoration in the Department of Stomatology of Xuzhou Stomatology Hospital from March 2014 to March 2015, were selected and randomly divided into four groups; namely, silver amalgam group, glass-ionomer cement group, nichrome group and novel nano-composite resin group, with 60 teeth in each group. The diseased teeth were restored. The fibroblast HGF-1 was incubated in the water extracts from the four kinds of materials and ordinary cell culture fluid (negative control). Reverse transcription-quantitative polymerase chain reaction (RT-qPCR) and western blotting were used to measure the levels of Bcl-2 and Bax. A flow cytometer was applied to detect cell apoptosis. RT-qPCR results showed that compared with those in the negative control group, the mRNA expression levels of Bcl-2 in the cells of silver amalgam group, glass-ionomer cement group and nichrome group were decreased, while those of Bax were upregulated $(\mathrm{P}<0.05)$. The mRNA expression of $\mathrm{Bcl}-2$ in glass-ionomer cement group was the highest among these three groups; the mRNA expression of Bax in nichrome group was the highest of all groups. The western blotting results revealed the same tendency as those of RT-qPCR. The results via the flow cytometer showed that cell apoptosis in nichrome group, silver amalgam group and glass-ionomer cement group was increased significantly $(\mathrm{P}<0.05)$ compared with that in the negative control group. The novel nano-composite resin has no
\end{abstract}

Correspondence to: Dr Jian Sun, Department of Endodontics, Xuzhou Stomatology Hospital, 130 Huaihaixi Road, Xuzhou, Jiangsu 221003, P.R. China

E-mail: whj2pz@163.com

Key words: dental restoration, nano-composite resin, silver amalgam, glass-ionomer cement, nichrome, cytotoxicity, apoptosis obvious toxic effect on cells, and its clinical application effect is better than that of traditional dental restorative materials, which is worthy of application and generalization in clinical practice.

\section{Introduction}

The composite repair material, such as metallic, ceramic and resin material, as well as glass-ionomer cement, is one of the numerous achievements in the research on modern biomaterials $(1,2)$; its biocompatibility is so good that it is comparable to biological tissues, providing great convenience for the mechanical property, in situ immobilization and beautiful outlook of the prostheses (3). However, when these materials are utilized for dental restoration treatment in current clinical practices, phenomena such as abnormal hyperplasia, swelling and aching, and increased secretion at gingival crevice often occur in the gingiva adjacent to the repair materials $(4,5)$. Therefore, searching for safe and effective dental restorative materials has become an urgent issue that needs to be addressed. In this research, the novel nano-composite resin researched and developed by the College of Materials Science and Engineering, Nanjing University (Nanjing, China) was applied and compared with conventional silver amalgam, glass-ionomer cement and nichrome to study the efficacy and cytotoxicity in clinical patients, and to determine the safety and effect of novel nano-composite resin material.

\section{Patients and methods}

Clinical data. One hundred and ninety-two patients (240 diseased teeth), who received dental restoration in the Department of Stomatology of Xuzhou Stomatology Hospital (Xuzhou, China) from March 2014 to March 2015, were selected and randomly divided into four groups, with 60 teeth in each group. With regard to different dental restorative materials applied, the groups were called silver amalgam group, glass-ionomer cement group, nichrome group and novel nano-composite resin group, respectively. The novel nano-composite resin material was researched and developed by the College of Materials Science and Engineering, Nanjing University, and the glass-ionomer cement, silver amalgam and 
nichrome materials were purchased from Shanghai Huifeng Medical Instrument Co., Ltd. (Shanghai, China).

Inclusion criteria of participants: i) patients with at least one defect tooth after oral examination, on which dental restoration needed to be performed; and ii) after root canal therapy, patients without apparent periodontal pain, percussion pain and shadow at the tooth root as well as notable widening around the root through X-ray examination (6). The side effects and complications of the patients were evaluated through follow-up at 1 month and 2 years later. Informed consent was signed by all the patients or the guardians. The study was approved by the Ethics Committee of Xuzhou Stomatology Hospital.

Preparation of water extracts. Four kinds of materials (silver amalgam, glass-ionomer cement, nichrome and novel nano-composite resin) were made into round pieces with a diameter of $10 \mathrm{~mm}$ and thickness of $1 \mathrm{~mm}$, respectively, followed by polishing, ultrasonic cleaning, disinfection with $75 \%$ alcohol and overnight ultraviolet radiation; later, 1 piece of each kind was placed in a 6-well plate for cell culture. According to China's national standard GB/T16886.521997 ('Biological evaluation criteria for medical devices - Part 5: Tests for in vitro cytotoxicity'), the ratio of the surface area of the material to the volume of the extraction medium should be $0.5-6 \mathrm{~cm}^{2} / \mathrm{ml}(7)$. In this study, this ratio was $1 \mathrm{~cm}^{2} / \mathrm{ml}$. Extract was DMEM containing 5\% fetal bovine serum. Based on previous studies, 6 -well plate was put in an incubator at $37^{\circ} \mathrm{C}$ and incubated for 1 week (8). In negative control group, DMEM containing 5\% fetal bovine serum, without any treatment, was adopted.

Cell culture. Human fibroblast cell line L-929 was purchased from the Cell Bank of the American Type Culture Collection (ATCC; Manassas, VA, USA). Cell culture was conducted in the high-glucose DMEM containing $10 \%$ fetal bovine serum, to which $100 \mu \mathrm{g} / \mathrm{ml}$ streptomycin and $100 \mathrm{IU} / \mathrm{ml}$ penicillin were added. The cell culture flask was placed in an incubator containing $5 \% \mathrm{CO}_{2}$ at $37^{\circ} \mathrm{C}$ with a humidity of $95 \%$.

Detection of the expression of apoptosis-related indexes [B-cell lymphoma-2 (Bcl-2) and Bcl-2-associated X protein (Bax)] via reverse transcription quantitative polymerase chain reaction $(R T-q P C R)$. After the cells were cultured in the four kinds of water extracts for $24 \mathrm{~h}$, respectively, RNeasy kit (Qiagen $\mathrm{GmbH}$, Hilden, Germany) was used to extract the total messenger RNA (mRNA). Total mRNA $(1.0 \mu \mathrm{g})$ was synthesized into complementary DNA (cDNA) using the reverse transcription kit (SuperScript ${ }^{\circledR}$ VILO $^{\text {TM }}$ cDNA Synthesis Kit and Master Mix; Thermo Fisher Scientific, Inc., Waltham, MA, USA). The expression of Bax and Bcl-2 was detected via the qRT-PCR kit (Guangzhou FulenGen Co., Ltd., Guangdong, China) and fluorescence-based RT-qPCR instrument (Thermo Fisher Scientific, Inc.). Glyceraldehyde-3-phosphate dehydrogenase (GAPDH) was adopted as the internal control of calibration for each sample. The formula for the relative mRNA expression of each index was $2^{-\Delta \Delta \mathrm{Cq}}[\Delta \mathrm{Cq}=\mathrm{Cq}$ (target gene) $-\mathrm{Cq}(\mathrm{GAPDH})](9)$. All the primers were synthesized by Sangon Biotech (Shanghai) Co., Ltd (Shanghai, China). The corresponding primer sequences are shown in Table I.
Table I. Primer sequences for RT-qPCR.

\begin{tabular}{ll} 
Gene name & \multicolumn{1}{c}{ Primer sequence } \\
\hline Bax & F: 5'-3' AGACAGGGGCCTTTTTGCTAC \\
& R: 3'-5' AATTCGCCGGAGACACTCG \\
Bcl-2 & F: 5'-3' GCTACCGTCGTGACTTCGC \\
& R: 3'-5' CCCCACCGAACTCAAAGAAGG \\
GAPDH & F: 5'-3' TGACTTCAACAGCGACACCCA \\
& R: 3'-5' CACCCTGTTGCTGTAGCCAAA
\end{tabular}

Bax, Bcl-2-associated X protein; Bcl-2, B-cell lymphoma-2; F, forward; R, reverse.

Detection of the expression of apoptosis-related indexes (Bcl-2 and Bax) via western blotting. After culturing in the four kinds of water extracts for $24 \mathrm{~h}$, respectively, the cells were lysed on ice with radio-immunoprecipitation assay (RIPA) lysis buffer (Beyotime Biotechnology, Guangzhou, China) for $1 \mathrm{~h}$, followed by extraction of protein supernatant through centrifugation at $13,000 \times \mathrm{g}, 4^{\circ} \mathrm{C}$ for $30 \mathrm{~min}$. Bicinchoninic acid (BCA) protein assay kit was applied to measure the protein concentration, and then an appropriate amount of loading buffer (both from Beyotime Biotechnology) was added for denaturation at $100^{\circ} \mathrm{C}$ for $5 \mathrm{~min}$. Every sample at an equal loading of $40 \mu \mathrm{g}$, underwent electrophoresis. Later, the proteins were transferred to the polyvinylidene fluoride (PVDF) membrane. Then the membrane was blocked in $5 \%$ skim milk at room temperature for $1 \mathrm{~h}$, followed by incubation of rabbit anti-human Bax, Bcl-2 and GAPDH monoclonal antibodies (1:2,000; cat nos. ab32503, ab32124 and ab181602; all from Abcam, Cambridge, UK). The membrane was washed with Tris-buffered saline and Tween-20 (TBST), and incubated with corresponding horseradish peroxidase-conjugated goat anti-rabbit secondary polyclonal antibody $(1: 5,000$; cat no. A0208; Beyotime Biotechnology, Shanghai, China). Later, an enhanced chemiluminescence (ECL) detection system (Bio-Rad Laboratories, Inc., Hercules, CA, USA) was utilized to visualize the membrane, and a gel analyzer (GraphPad Prism 5; GraphPad Software, Inc., La Jolla, CA, USA) was applied for gray analysis. The relative content of the target protein was the ratio of the target protein to gray value of the corresponding internal control band.

Detection of the cell apoptosis level via flow cytometer. The apoptosis level of cells in each group was measured using an apoptosis kit (BD Biosciences, Franklin Lakes, NJ, USA). After the cells were treated with different water extracts for $48 \mathrm{~h}$, the cell culture fluids were absorbed and reserved, which were centrifuged at $850 \mathrm{x}$ g for $5 \mathrm{~min}$ together with the digested cells, followed by washing with phosphate-buffered saline (PBS) and centrifugation twice. After that, the samples were resuspended in $100 \mu \mathrm{l} 1 \mathrm{X}$ binding buffer, to which $5 \mu \mathrm{l}$ propidium iodide (PI) and $5 \mu \mathrm{l}$ Annexin $\mathrm{V}$ were added, followed by incubation in the dark at room temperature for $15 \mathrm{~min}$. Then the samples were sent to the scientific research center of the hospital within $1 \mathrm{~h}$ for detection by a flow cytometer (FACSCalibur; BD Biosciences, Detroit, 
Table II. General information of patients (mean \pm SD).

\begin{tabular}{lcccc}
\hline Items & $\begin{array}{c}\text { Silver amalgam } \\
\text { group (n=60) }\end{array}$ & $\begin{array}{c}\text { Novel nano-composite } \\
\text { resin group (n=60) }\end{array}$ & $\begin{array}{c}\text { Glass-ionomer cement } \\
\text { group (n=60) }\end{array}$ & $\begin{array}{c}\text { Nichrome group } \\
(\mathrm{n}=60)\end{array}$ \\
\hline Age (years) & $37.34 \pm 12.83$ & $35.48 \pm 14.02$ & $36.16 \pm 14.23$ & $37.15 \pm 15.03$ \\
Sex & & & & 0.765 \\
Male & 33 & 31 & 26 & 32 \\
Female & 27 & 29 & 34 & 28 \\
Anterior tooth (n) & 18 & 21 & 18 & 20 \\
Premolar (n) & 22 & 17 & 19 & 0.926 \\
Molar (n) & 20 & 22 & 23 & 0.738 \\
\end{tabular}

There is no statistically significant difference in age, sex and tooth structure among the four groups of patients $(\mathrm{P}>0.05)$.

Table III. Patient complications at 1 month after repair.

\begin{tabular}{lcccc}
\hline Items & $\begin{array}{c}\text { Silver amalgam } \\
\text { group }(\mathrm{n}=60)\end{array}$ & $\begin{array}{c}\text { Novel nano-composite } \\
\text { resin group }(\mathrm{n}=60)\end{array}$ & $\begin{array}{c}\text { Glass-ionomer cement } \\
\text { group }(\mathrm{n}=60)\end{array}$ & $\begin{array}{c}\text { Nichrome group } \\
(\mathrm{n}=60)\end{array}$ \\
\hline Bleeding & 3 & 1 & 1 & 3 \\
Local anaphylaxis & 2 & 0 & 0 & 3 \\
Gingival inflammation & 3 & 0 & 2 & 1 \\
Oral ulcer & 0 & 0 & 3 & 4 \\
Toothache & 2 & 1 & $6(10 \%)$ & $12(20 \%)$ \\
Total cases & $10(16.7 \%)$ & $2(3.3 \%)$ & 0 & 4 \\
\hline
\end{tabular}

MI, USA). Cell apoptosis rate = early apoptosis rate + late apoptosis rate.

Statistical methods. GraphPad Prism software (version 5.01) was used for the statistical analysis of the experimental results. The data were expressed as mean $\pm \mathrm{SD}$. The one-way analysis of variance (ANOVA) was applied to compare the differences in indexes among multiple groups and the least significant difference (LSD) test was the post hoc test used. $\mathrm{P}<0.05$ was considered to indicate a statistically significant difference.

\section{Results}

General information of patients. As shown in Table II, there was no statistically significant difference in age, sex and tooth structure among the four groups of patients $(\mathrm{P}>0.05)$.

Patient complications at 1 month after repair. The follow-up results at 1 month after the treatment of the patients showed (Table III) that in silver amalgam group, there were 3 cases of bleeding, 2 cases of local anaphylaxis, 3 cases of gingival inflammation and 2 cases of toothache; in novel nano-composite resin group, there was 1 case of bleeding and toothache, respectively; in glass-ionomer cement group, there was 1 case of bleeding, 2 cases of gingival inflammation and 3 cases of toothache; in nichrome group, the cases of bleeding, local anaphylaxis, gingival inflammation, oral ulcer and toothache were 3,3,1,1 and 4, respectively. At 1 month after the treatment there was no statistically significant difference in the total number of diseased teeth between nichrome group and control group $(\mathrm{P}>0.05)$; the total number of diseased teeth in novel nano-composite resin group and glass-ionomer cement group was significantly decreased compared with that in control group $(\mathrm{P}<0.05)$, of which the total number of diseased teeth in novel nano-composite resin group was smaller than that in glass-ionomer cement group $(\mathrm{P}<0.05)$.

Conditions of diseased teeth at 2 years after repair. The follow-up results at 2 years after the treatment of the patients showed (Table IV) that in silver amalgam group, there were 9 cases of marginal black line, 4 cases of secondary caries and 1 case of tooth fracture; in novel nano-composite resin group, there was 1 case of looseness and loss of tooth as well as 1 case of fracture; in glass-ionomer cement group, there were 3 cases of marginal black line, 3 cases of looseness and loss, 1 case of tooth fracture and 2 cases of dental abnormality; in nichrome group, there were 8 cases of marginal black line, 5 cases of secondary caries and 2 cases of looseness and loss. At 2 years after treatment there was no statistically significant difference in the total number of diseased teeth between nichrome group and control group $(\mathrm{P}>0.05)$; the total number of diseased teeth in novel nano-composite resin group and glass-ionomer cement group was significantly decreased compared with that in control group $(\mathrm{P}<0.05)$, of which the total number of diseased teeth in novel nano-composite resin group was smaller than that in glass-ionomer cement group $(\mathrm{P}<0.05)$. 
Table IV. Conditions of diseased teeth at 2 years after repair.

\begin{tabular}{lcccc}
\hline Items & $\begin{array}{c}\text { Silver amalgam } \\
\text { group }(\mathrm{n}=60)\end{array}$ & $\begin{array}{c}\text { Novel nano-composite } \\
\text { resin group }(\mathrm{n}=60)\end{array}$ & $\begin{array}{c}\text { Glass-ionomer cement } \\
\text { group }(\mathrm{n}=60)\end{array}$ & $\begin{array}{c}\text { Nichrome group } \\
(\mathrm{n}=60)\end{array}$ \\
\hline Marginal black line & 9 & 0 & 3 & 8 \\
Secondary caries & 4 & 0 & 0 & 5 \\
Looseness and loss & 0 & 1 & 3 & 2 \\
Fracture & 1 & 1 & 1 & 0 \\
Abnormality & 0 & 0 & 2 & 0 \\
Total cases & $14(23.3 \%)$ & $2(3.3 \%)$ & $9(15 \%)$ & $15(25 \%)$ \\
\hline
\end{tabular}

Detection of the apoptosis-related indexes via RT-qPCR. As shown in Fig. 1, there was no statistically significant difference in the mRNA expression levels of Bax and Bcl-2 between the cells in novel nano-composite resin group and negative control group $(\mathrm{P}>0.05)$. Compared with those in the negative control group, the mRNA expression levels of the pro-apoptotic index Bax were remarkably upregulated in glass-ionomer cement group, silver amalgam group and nichrome group, from the lowest to the highest $(\mathrm{P}<0.05)$. However, the mRNA expression of the anti-apoptotic index Bcl-2 in glass-ionomer cement group was higher than that in silver amalgam group and nichrome group, which were notably downregulated $(\mathrm{P}<0.05)$

Detection of the apoptosis-related indexes via western blotting. As indicated in Fig. 2, the protein trends and mRNA trends of Bax and Bcl-2 in the five treatment groups of cells were the same. The differences in the protein levels of Bax and $\mathrm{Bcl}-2$ between the cells in novel nano-composite resin group and negative control group were no statistically significant $(\mathrm{P}>0.05)$. Compared with those in the negative control group, the protein levels of the pro-apoptotic index Bax were remarkably upregulated in glass-ionomer cement group, silver amalgam group and nichrome group, from the lowest to the highest $(\mathrm{P}<0.05)$. However, the protein level of the anti-apoptotic index Bcl-2 in glass-ionomer cement group was higher than that in silver amalgam group and nichrome group, which were notably downregulated $(\mathrm{P}<0.05)$.

Detection of cell apoptosis via the flow cytometer. The Annexin V/PI double staining was applied to label the early and late apoptotic cells. The results indicated that the cell apoptosis level in novel nano-composite resin group was not statistically different from that in the negative control group $(\mathrm{P}>0.05)$. Compared with that in the negative control group, the cell apoptosis level in glass-ionomer cement group, silver amalgam group and nichrome group was increased $(\mathrm{P}<0.05)$ (Fig. 3)

\section{Discussion}

Dentistry is gradually developing into a complex biomedical discipline $(10,11)$, and materials such as silver amalgam and glass-ionomer cement have made great contribution to clinical practices over the past decades (12). The color of silver amalgam is similar to that of the teeth, so that this kind of material is still widely used by dentists at present. Studies
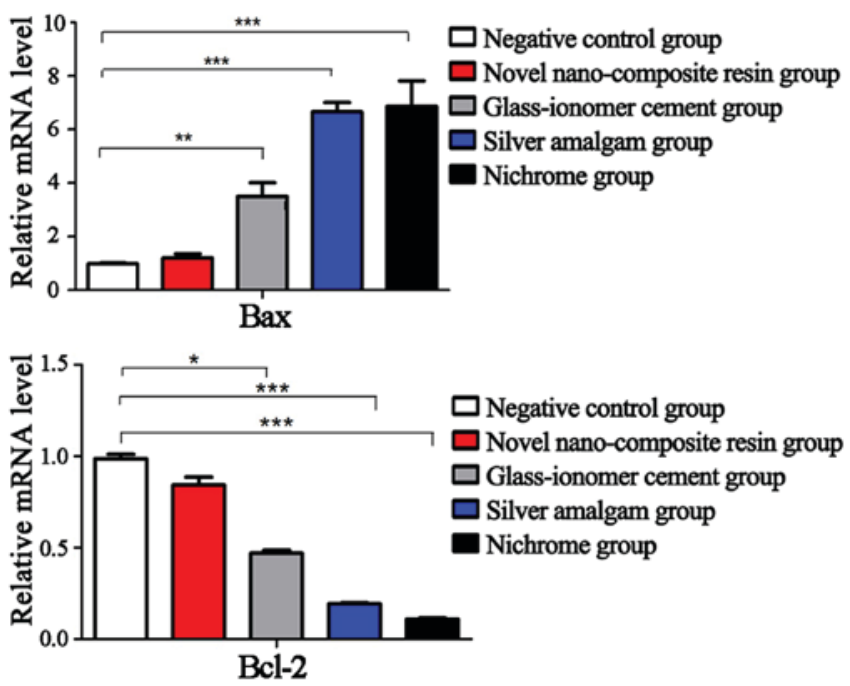

Figure 1. Detection of mRNA expression of Bax and Bcl-2 in five groups of cells via RT-qPCR. There is no significant difference in the mRNA expression levels of Bax and Bcl-2 between the cells in novel nano-composite resin group and negative control group $(\mathrm{P}>0.05)$; however, the mRNA expression levels of Bax in the cells of the remaining three groups is obviously increased, and those of $\mathrm{Bcl}-2$ are significantly downregulated $(\mathrm{P}<0.05)$. Compared with control group, ${ }^{*} \mathrm{P}<0.05,{ }^{* *} \mathrm{P}<0.01,{ }^{* * *} \mathrm{P}<0.001$. Bax, $\mathrm{Bcl}-2$-associated $\mathrm{X}$ protein; Bcl-2, B-cell lymphoma-2; RT-qPCR, reverse transcription quantitative polymerase chain reaction.

published so far have revealed that silver amalgam clearly does not meet the requirements for safety and longevity, and that the physical, chemical and biological characteristics of the materials currently utilized in restorative dentistry need to be re-evaluated (13). The conventional glass-ionomer cement is made of glass (e.g., calcium-aluminosilicate glass) and polycarbonate (propylene carbonate). These materials were once considered as possible substitutes for silver amalgam filling due to their good biocompatibility (14). Although the newly developed composite materials have improved their physicochemical properties, in vitro studies have indicated that the intrinsic toxicity of glass-ionomer cement is still very high (15).

Firstly, the free monomers released by the conventional dental restorative materials (glass-ionomer cement and nichrome) are conducive to the proliferation of bacteria, especially the microorganisms related to the formation of dental caries, which are helpful in the occurrence of secondary caries (16). Secondly, the cellular and molecular mechanisms 

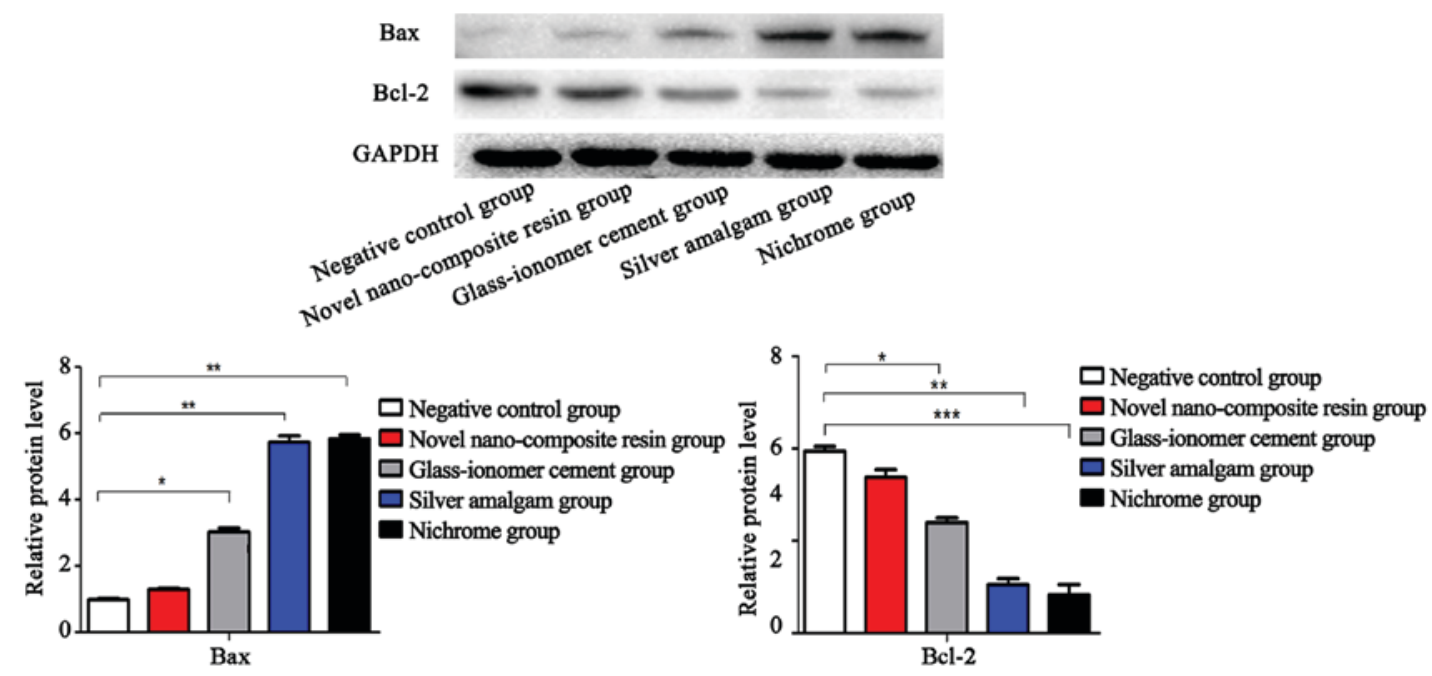

Figure 2. Detection of protein status of Bax and Bcl-2 in five groups of cells via western blotting. There is no significant difference in the protein levels of $\mathrm{Bax}$ and Bcl-2 between the cells in novel nano-composite resin group and negative control group $(\mathrm{P}>0.05)$; however, the protein levels of Bax in the cells of the remaining three groups are obviously upregulated, and those of $\mathrm{Bcl}-2$ are significantly downregulated $(\mathrm{P}<0.05)$. Compared with control group, ${ }^{*} \mathrm{P}<0.05$, ${ }^{* *} \mathrm{P}<0.01,{ }^{* * *} \mathrm{P}<0.001$. Bax, Bcl-2-associated X protein; Bcl-2, B-cell lymphoma-2.
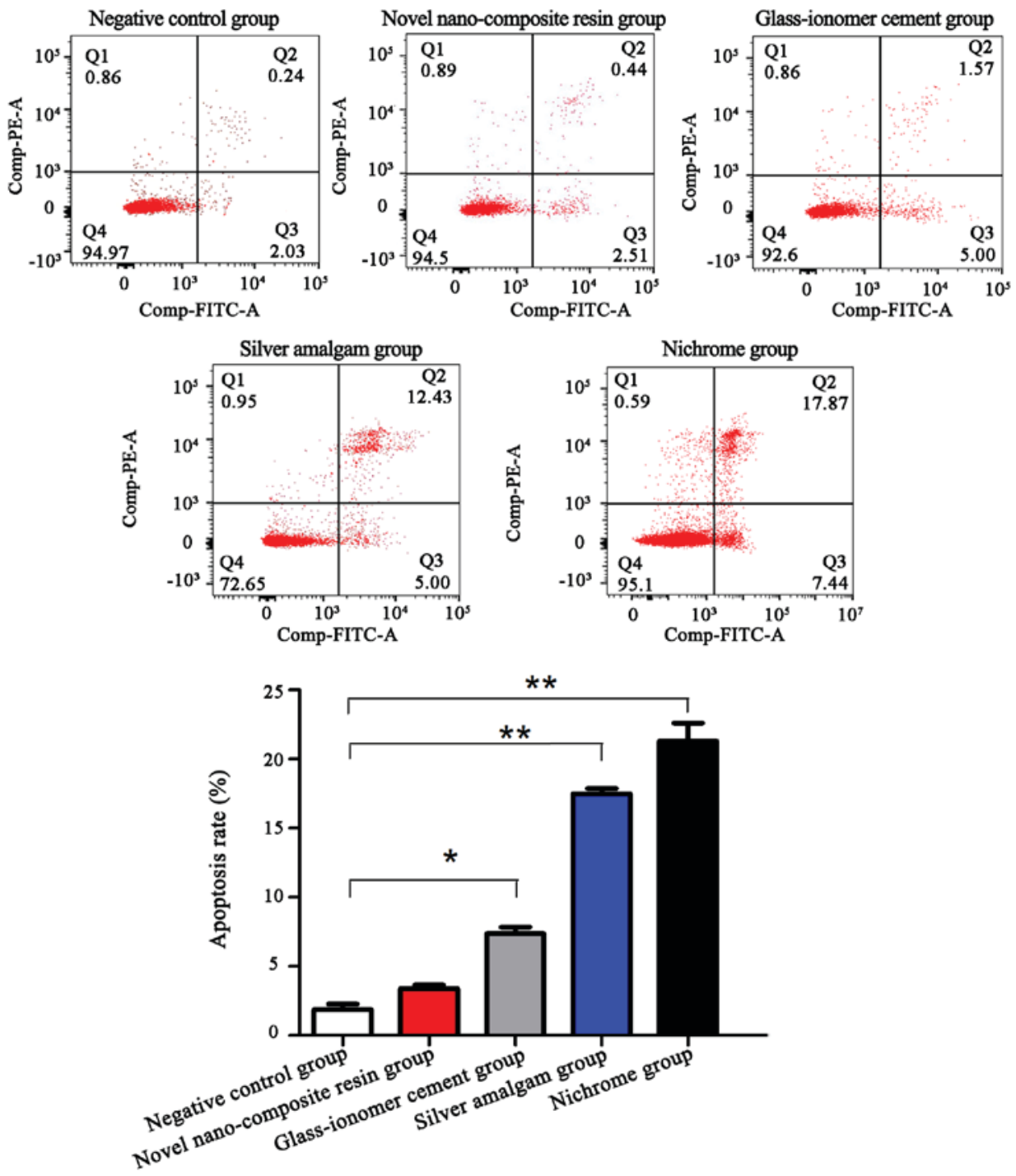

Figure 3. Detection of apoptosis in five groups of cells via the flow cytometer. The cell apoptosis level in novel nano-composite resin group is not statistically different from that in negative control group $(\mathrm{P}>0.05)$. Compared with that in the negative control group, the cell apoptosis level in glass-ionomer cement group, silver amalgam group and nichrome group is significantly increased $(\mathrm{P}<0.05)$. Compared with control group, ${ }^{\mathrm{P}} \mathrm{P}<0.05,{ }^{* *} \mathrm{P}<0.01$. Bax, Bcl-2-associated $\mathrm{X}$ protein; Bcl-2, B-cell lymphoma-2. 
of cytotoxicity are triggered by the monomers, which lead to dental pulp changes and marginal gingival recession (17). Thirdly, some literature reports have revealed that silver amalgam can cause local and systemic anaphylaxis (18). In our research, there were 2 cases of local anaphylaxis in silver amalgam group.

However, the major side effect of conventional dental restorative materials is cytotoxicity. Specifically, the mechanism of cytotoxicity is firstly correlated with the short-term release of free monomers in the monomer-polymer transformation process. Relevant studies have revealed that the molecular mechanism that involves the glutathione depletion and reactive oxygen species (ROS) generation is the key factor for apoptosis of dental pulp or gingiva (19-21). Rai et al identified that glass-ionomer cement can produce cytotoxicity to human dental pulp and gingiva cells (18). Stanislawski et al found that some nichrome materials have toxic effects on the primary fibroblasts of rabbit pulp (19). The study of Geurtsen et al indicated that the release of metal ions may be a reason for silver amalgam generating toxicity to cells in vitro (22). Consistent with these research results, the anti-apoptotic index $\mathrm{Bcl}-2$ and pro-apoptotic index Bax were examined via western blotting. It was discovered that the protein levels of Bcl-2 were obviously decreased in the water extracts of glass-ionomer cement group, silver amalgam group and nichrome group, and those of Bax were elevated. The results through flow cytometer suggested that the water extracts of glass-ionomer cement, silver amalgam and nichrome also significantly promoted the apoptosis of fibroblast L-929. The patients' complications at 1 month and 2 years after the dental restoration in the three groups were remarkably higher than those in novel nano-composite resin group; however, the water extract from novel nano-composite resin had no significant impact on the Bcl-2 and Bax protein levels of L-929 cells, and there was no statistically significant difference in apoptosis level of L-929 cells compared with that in negative control group.

In addition, secondary caries is the most common complication after dental restoration (23). Conventional resin materials shrink during the polymerization process, leaving a space surrounded by bacteria between the material and cavity wall, while the so-called mixing layer even has bacteria infiltrating, which is conducive to the occurrence of secondary caries $(24,25)$. The novel nano-composite resin utilized in this experiment was the nano-repair material made of silicon dioxide and zirconium oxide which had stable chemical properties, hard texture and luster and quality of natural enamel. It was manifested in this experiment that the conditions of bleeding, local anaphylaxis, gingival inflammation, toothache, oral ulcer and other diseases at 1 month and 2 years after the use of the novel nano-composite resin to patients, as well as its service conditions, were superior to those of the other three kinds of conventional materials.

In conclusion, the impacts of silver amalgam, glass-ionomer cement, nichrome and novel nano-composite resin on the toxicity of fibroblasts, as well as the effects of their use on clinical patients, were mainly compared in this study. The results showed that the novel nano-composite resin has no toxic effect on the fibroblast L-929, and its clinical side effects are remarkably fewer than those of conventional materials; due to these advantages, it is worthy of application and generalization in clinical practice.

\section{Acknowledgements}

Not applicable.

\section{Funding}

No funding was received.

\section{Availability of data and materials}

The datasets used and/or analyzed during the present study are available from the corresponding author on reasonable request.

\section{Authors' contributions}

YW and JS conceived and designed the study. YW, QM and $\mathrm{XT}$ were responsible for the collection and analysis of the patient data. JS and QM interpreted the data and drafted the manuscript. YW revised the manuscript critically for important intellectual content. All authors read and approved the final manuscript.

\section{Ethics approval and consent to participate}

The study was approved by the Ethics Committee of Xuzhou Stomatology Hospital (Xuzhou, China). Signed informed consents were obtained from the patients or the guardians.

\section{Patient consent for publication}

Not applicable.

\section{Competing interests}

The authors declare that they have no competing interests.

\section{References}

1. Wang Y, He J, Li Q and Shen J: Preparation of sodium alginate-nanohydroxyapatite composite material for bone repair and its biocompatibility. Hua Xi Kou Qiang Yi Xue Za Zhi 32: 27-31, 2014 (In Chinese).

2. Kawajiri H, Yamanami M, Mizuno T, Kanda K, Yaku H and Nakayama Y: Feasibility of connective tissue membrane (bio-sheet) prepared in the body as cardiovascular repair material as a substitute for self-pericardium. Circulation 128: A12910, 2013.

3. Croll TP, Berg JH and Donly KJ: Dental repair material: A resin-modified glass-ionomer bioactive ionic resin-based composite. Compend Contin Educ Dent 36:60-65, 2015.

4. Cvar JF and Ryge G: Reprint of criteria for the clinical evaluation of dental restorative materials. 1971. Clin Oral Investig 9: 215-232, 2005.

5. Zhou HM, Shen Y, Wang ZJ, Li L, Zheng YF, Häkkinen L and Haapasalo M: In vitro cytotoxicity evaluation of a novel root repair material. J Endod 39: 478-483, 2013.

6. Sang Z, Liu ZY, Gu YD and Feng JN: Evaluation and analysis on clinical effects of different dental restorative materials. J Taishan Med Coll 37: 907-909, 2016.

7. Abedi G, Jahanshahi A, Fathi MH, Haghdost IS and Veshkini A: Study of nano-hydroxyapatite/zirconia stabilized with yttria in bone healing: Histopathological study in rabbit model. Pol J Pathol 65: 40-47, 2014. 
8. Wataha JC, Nelson SK and Lockwood PE: Elemental release from dental casting alloys into biological media with and without protein. Dent Mater 17: 409-414, 2001.

9. Livak KJ and Schmittgen TD: Analysis of relative geneexpression data using real-time quantitative PCR and the2(-Delta Delta C(T)) method. Methods 25: 402-408, 2001.

10. Anusavice K, Shen C and Rawls HR (eds): Phillips' Science of Dental Materials. 12th edition. Saunders, 2012.

11. Feinberg M, Garcia LT, Polverini PJ, Fox CH and Valachovic RW: The vital role of research funding in preserving the oral health of the public and the dental profession. J Am Dent Assoc 146: 355-356, 2015.

12. Mickenautsch S: Are high-viscosity glass-ionomer cements inferior to silver amalgam as restorative materials for permanent posterior teeth? A Bayesian analysis. BMC Oral Health 15: 118, 2015.

13. Saghiri MA, Banava S, Sabzian MA, Gutmann JL, Asatourian A, Ramezani GH, Garcia-Godoy F and Sheibani N: Correlation between long-term in vivo amalgam restorations and the presence of heavy elements in the dental pulp. J Trace Elem Med Biol 28: 200-204, 2014.

14. Mickenautsch S: Retention of GIC versus Amalgam as restorations [October 06, 2015]. J Minim Inter Dent 9: 28-30, 2016.

15. Chen S, Mestres G, Lan WH, Xia W and Engqvist H: In vitro cytotoxicity of dental cements on odontoblast cells. Presented at Towards Future Regenerative Therapies TERMIS-EU 2016 Conference. (abstract P87), 2016. http://ecmconferences. org/abstracts/2016/Collection1/c1_poster.html.

16. Kuper NK, Montagner AF, van de Sande FH, Bronkhorst EM, Opdam NJ and Huysmans MC: Secondary caries development in in situ gaps next to composite and amalgam. Caries Res 49: $557-563,2015$

17. De Munck J, Van Landuyt K, Peumans M, Poitevin A, Lambrechts P, Braem M and Van Meerbeek B: A critical review of the durability of adhesion to tooth tissue: Methods and results. J Dent Res 84: 118-132, 2005.
18. Rai R, Dinakar D, Kurian SS and Bindoo YA: Investigation of contact allergy to dental materials by patch testing. Indian Dermatol Online J 5: 282-286, 2014.

19. Stanislawski L, Soheili-Majd E, Perianin A and Goldberg M: Dental restorative biomaterials induce glutathione depletion in cultured human gingival fibroblast: Protective effect of N-acetyl cysteine. J Biomed Mater Res 51: 469-474, 2000.

20. Goldberg M, Stanislawski L, Bonte E, Daniau X, Bonte E, Daniau X and Lasfargues JJ: Biocompatibility of glass-ionomer cements. In: Advances in Glass-Ionomer Cements. Davidson CL and Mjör IA (eds). 1st edition. Quintessence Publishing Co., Chicago, pp103-120, 1999.

21. Szep S, Kunkel A, Ronge K and Heidemann D: Cytotoxicity of modern dentin adhesives - in vitro testing on gingival fibroblasts. J Biomed Mater Res 63: 53-60, 2002.

22. Geurtsen W, Lehmann F, Spahl W and Leyhausen G: Cytotoxicity of 35 dental resin composite monomers/additives in permanent 3T3 and three human primary fibroblast cultures. J Biomed Mater Res 41: 474-480, 1998.

23. Fontana M and González-Cabezas C: Secondary caries and restoration replacement: An unresolved problem. Compend Contin Educ Dent 21: 15-18, 21-24, 26 passim, quiz 30, 2000.

24. Zhang N, Melo MA, Chen C, Liu J, Weir MD, Bai Y and Xu HH: Development of a multifunctional adhesive system for prevention of root caries and secondary caries. Dent Mater 31: 1119-1131, 2015.

25. Schwendicke F, Kern M, Blunck U, Dörfer C, Drenck J and Paris S: Marginal integrity and secondary caries of selectively excavated teeth in vitro. J Dent 42: 1261-1268, 2014.

This work is licensed under a Creative Commons Attribution-NonCommercial-NoDerivatives 4.0 International (CC BY-NC-ND 4.0) License. 